\title{
Innovation Determinants over Industry Life Cycle
}

\author{
Sam Tavassoli \\ Department of Industrial Economics \\ Blekinge Institute of Technology (BTH), 37179 Karlskrona, Sweden \\ Phone: +46 455385688 \\ E-mail: sam.tavassoli@bth.se
}

\begin{abstract}
This paper analyzes how the influence of firm-level innovation determinants varies over the industry life cycle. Two sets of determinants are distinguished: (1) determinants of a firm's innovation propensity, i.e. the likelihood of being innovative and (2) determinants of its innovation intensity, i.e. innovation sales. By combining the literature emphasizing firms' internal resources (micro level) with the research strand on the role of the industry context (mesolevel), the paper develops hypotheses about the relative importance of firm-level innovation determinants over the industry life cycle. Estimation of a firm-level model of innovation in Sweden, while acknowledging the stage of the life cycle of the industry a firms belongs to, shows that the importance of the determinants of innovation propensity and intensity are not equal over the stages of an industry's life cycle.
\end{abstract}

Keywords: Determinants of innovation; innovation intensity; innovation propensity; Industry Life Cycle (ILC); Community Innovation Survey (CIS4) 


\section{Introduction}

Firms' innovation efforts and outcomes take place in contexts. One of the contexts in which innovation happens is provided by the industry in which firms operate in. A large literature on industry life cycles (ILC) emphasizes that the stage of the life cycle of the industry in which a firm operates provide an important context for innovation [1] [2] [3] [4] ${ }^{1}$. The stage of the ILC is often claimed to be an important factor influencing the dynamics and behavior of firms, particularly innovative behavior [5]. This has been a recurrent argument in the evolutionary school of economics [6], and in particular the literature on technological regimes [7]. However, one aspect that is seldom dealt with is if and to what extent the stage of an ILC influences the relative importance of firm-level innovation determinants ${ }^{2}$. The aim of this paper is to fill this gap in the literature.

This paper provides an empirical analysis on how the relative importance of firm-level innovation determinants varies over the stages of ILC in which firms operate and innovate. This is done by bringing together micro (firm-level innovation studies) and meso level arguments (ILC literature) in which innovation happens, and testing them in a common empirical setting. While this is rarely done in the literature, it is frequently called for [8, p. 206]. Apart from such contribution, the paper has a number of novelties. In particular, it employs firm-level Community Innovation Survey (CIS) data, allowing for a direct measure of innovation and a distinction between determinants of innovation propensity (probability of being innovative) and intensity (innovation sales), respectively. Such distinction is beneficial (at least) from theoretical point of view (this will be discussed in section 4). The paper also adapts various established methods to empirically identify stages of industry life cycles.

Using firm-level CIS4 data for Sweden, it is shown that firm's innovation investment has the highest explanatory power for innovation intensity of firms in growing industries. Size is more pronounced to explain likelihood of being innovative for firms in mature industries. Finally, engagement in international trade appears to be the most influential determinant for innovation propensity of firms in declining industries. The analyses provide a better understanding of the significance of innovation determinants over the ILC, which may lead to a better contingency approach for firms as well as policy makers with regard to innovation strategy and policy.

\footnotetext{
${ }^{1}$ The (product) life cycle concept can be can be traced back at least to the work by [64].

${ }^{2}$ Several studies address various 'aspects' of innovation through the stages of ILC: who innovate [5] [60] [3], how much innovation [61] [3] [44], what mode of innovation [42], and where innovation takes place [45]. The aspect that this paper is dealing with is what makes innovation, i.e. determinants of innovation, which seems rare in literature.
} 
The rest of the paper is organized as follows. Section 2 builds hypotheses concerning the relative importance of each innovation determinants based on ILC stages. This is done by describing important innovation determinants briefly and weaving it with the specific characteristics of each stages of ILC. Section 3 develops empirical methods for identification of the stages of the ILC. Section 4 describes the dataset, presents the firm-level model of innovation, tests the hypotheses by empirical estimation, and discusses the main results. Section 5 summarizes, concludes and discusses further research.

\section{Determinants of Innovation and Industry Life Cycle}

The main argument of this paper is that the role of different firm-level innovation determinants depends on the stage of the industry in which firms operate. The overall reason for such claim is that the meso-level context (here referring to stage of ILC) does matter for firm-level innovation, which is motivated by evolutionary economics [6] and particularly by technological regime literature [7]. As Malerba [9, p. 387] noted "heterogeneous firms [within a same industry] facing similar technologies, searching around similar knowledge bases, undertaking similar production activities, and embedded in the same institutional setting, share some common behavioral traits and develop a similar range of learning patterns, behavior, and organizational form" ${ }^{3}$. Section 2.1 and 2.2 develop the hypothesis concerning the relative importance of the innovation determinants over stages of ILC, by distinguishing them into two groups: determinants of innovation propensity and innovation intensity.

\subsection{Determinants of innovation propensity}

In line with neo-Schumpeterian literature and the resource based view (RBV), one of the determinants of innovation propensity of firms is shown to be human capital (or skilled labor). Human capital is considered as reflecting a firm's capacity to absorb, assimilate and develop 'new knowledge and technology' [10] [11]. The more such new knowledge and technology, the more innovation propensity of the firms is expected [12] [13].

\footnotetext{
${ }^{3}$ There is indeed a recent and alternative approach arguing that industries do not account for the considerable fraction of variance observed in firm's innovation strategy [67] [68]. Therefore, the result of the analysis of this paper is only valid assuming to accept the standard industry classification and the systematic difference between industries in their innovative behavior. While it is not a perfect assumption, nevertheless the debate between two approaches seems to be still open, so no strict preference seems to be established in favor of the alternative approach.
} 
The crucial point is that such new knowledge (leading to higher innovation propensity) is needed and also generated mostly in the 'early stage' of ILC, in compare with later stages. This is because in the early stage of the ILC, product and market situation is uncertain and in order to overcome such uncertainty and reaching to the dominant design, there is a need for the generation of new knowledge and innovation [14] [1]. As noted before, it is usually assumed that such knowledge generation and development is accomplished mostly by human capital (skilled labor). This can be interpreted as the relative importance of human capital in the early stage of ILC (i.e. growing industries) in compare with later stages. Such statement is clearly concluded in [5, p. 571] : "an industry tends to rely on the highest component of skilled labor during the early stages of the life-cycle, and the least amount of skilled labor after the product has become standardized in the mature and declining phases".

More specifically, the reason for such statement could be the fact that growing stage of ILC is usually characterized by labor-intensity rather than capital-intensity [15] [5]. Accordingly, [16] provide empirical evidence showing that firms entering/exiting in early stages of the product life cycle are more knowledge-intensive than their counterparts in later stages. Hirsch [15] already argued that 'human capital' can be more influential for production (of innovation) in the growing industries, while capital and unskilled labor are the most important production factors in the mature (and declining) stage(s). Recent empirical evidences also emphasized the importance of skilled labor in the growing stage of industries [17], while noting even negative effect of it in later stages [18]. This is again because of lack of dominant design in the growing industries and the more pronounced need for the generation of new knowledge, which is assumed to be accomplished by skilled labor (human capital).

Moreover, comparing the role of human capital in earlier versus later stages of ILC could be analogical to compare Schumpeter Mark I/entrepreneurial regime versus Schumpeter Mark II/routine regime, respectively, where the role of human capital is argued to be more pronounced for the sake of higher innovation propensity in the former rather than the later regime ${ }^{4}$. The relative importance of human capital has been also studies over the stages (age) of the plants, and similar evidence has been found in line with the studies over the stages of ILC: the importance of human capital is declining as the age of the plant is increasing [10].

To sum up, human capital is mostly responsible for generation of new knowledge within the firms and the more new knowledge the more innovation propensity for firms. Importantly, the need for generation of new knowledge is expected to be more pronounced in the growing stage

\footnotetext{
${ }^{4}$ The terminology 'entrepreneurial regime' versus 'routine regime' is associated with [65].
} 
of ILC in compare with later stages, and hence the need for human capital (as the generator of such new knowledge). Therefore, the first hypothesis is formulated as follows:

Hp1: Human capital is more important for innovation propensity of the firms in growing industries than the firms in other stages of ILC.

Another determinant of innovation propensity of firms is considered to be the 'size' of the firms. The size reflects access to finance and scale economies [19]. Such access to finance and scale economies play a crucial role for firms to increase (i) advertisement power (leading to product differentiation) [20] and (ii) scope economies for R\&D (provided by scale economy in production) [21].

However, innovation studies provide different evidences concerning the exact role of firm size and the innovation propensity. Some studies show that the likelihood of being innovative is positively related to the size of firms [22] [23] [19]. Other studies provide evidence in favor of the high propensity to innovate among the very small firms [24]. One possible explanation for such diverse results can be considering the context in which innovation happens, i.e. (again) stage of ILC.

There are indeed evidences showing that large firms probably have competitive advantageous over small ones within 'mature' industries, whereas small firms have competitive advantageous in growing industries [5]. The reason can be stated based on modified Schumpeterian hypothesis concerning innovation patterns: mature industries are commonly characterized as capitalintensive industries and existence of such capital-intensity tends to provide a concentrated market and higher appropriability to innovation, leading to impose the entry barriers to small-firm innovation, while relatively promoting large-firm innovation [15] [5] [7]. Further elaboration is already provided by Vernon [14] who defined the later stages of the (product) life cycle as the presence of a standardized product concept in the market, which is characterized by the existence of a mature technology. There is not that much needs to the rapid change and evolution of the products any more, instead, a relatively high level of (physical) capital is required in this stage for higher innovation propensity (mostly toward process innovation). On the other hand, the size of the firm seems not to be very crucial (and even harmful in some cases) for innovation of firms in 'growing' industries. Pavitt and Wald [25] argued that small-firms have innovative advantage in industries in the early stages of the life-cycle (where the use of skilled labor plays a large role).

To sum up, it is argued that large firms probably have competitive advantageous over small ones within mature industries (due to existence of capital-intensity), hence, the probability to 
innovate is expected to be higher for larger firms in these industries. These large firms in mature stage of ILC are presumably more able to (and also more willing to) invest heavily in innovation activities, specifically toward process innovation [1] [26] [27]. This can be interpreted as indicating the relatively higher importance of 'size' for increasing the probability of being innovative for firms in the mature industries (in compare with firms in other stages) ${ }^{5}$.

Hp2: Size is more important for innovation propensity of the firms in mature industries than the firms in other stages of ILC.

Firms engaged in international trade are regularly claimed to have better access to foreign knowledge and technology, hence higher propensity to innovation, since international trade is assumed to act as a conduit for flow of knowledge for firms $[28]^{6}$. Such argument is backed up by Learning-By-Exporting literature, too [29] [30] [31]. Moreover, there are empirical evidences showing the importance of engagement in import for firm's performance [32] [33] [34] ${ }^{7}$. Similar argument has been also raised by economic geographers by noting the importance of "global pipeline" (i.e. import and export) as a source of knowledge for firms' innovativeness [35] .

However, engagement in international trade requires overcoming the fixed and sunk costs of such engagements, which in turn require considerable physical capital stock [36] [37]. The large firms are usually assumed as the ones who own such capital stock and can afford such costs. Furthermore, the large firms are visible more in later stages of ILC (in line with Schumpeter Mark II) in contrast with earlier stage which is dominated by small firms (Schumpeter Mark I). This implies that the (large) firms in later stages are usually more 'capable' of engaging in international trade in compare with firms in earlier stage. More importantly, it is shown that large firms in declining industries are in fact more 'in need' of such access to international sources of knowledge input in compare with firms in earlier stages [38]. This is because firms in declining industries experience diminishing return from localization economies (i.e. local labor, supplier, and knowledge spillover) [18], hence for staying innovative these firms need to refresh their

\footnotetext{
${ }^{5}$ There are studies analyzing the effect of various innovation determinants on each other, e.g. 'skilled labor' found to be particularly important for innovation of 'small' firms [66] and even more important for innovation of very small firms compared to other firms [24]. However, these are out of the scope of this paper.

${ }^{6}$ Furthermore, there are empirical evidences showing firms that both export and import (i.e. two-way traders) are more productive than firms that only export or only import [53].

${ }^{7}$ However, these empirical evidences are mostly concern with productivity and not directly talking about innovation.

${ }^{8}$ Accordingly, Morrison [63] emphasize the international knowledge sources by proposing the role of "knowledge gatekeepers", which are the leader firms within the regions that feed the local firms with the knowledge absorbed and translated from external knowledge sources.
} 
knowledge stock through networks of international trade [39] [38]. Therefore, not only large firms in declining industries are more 'capable' of engaging in international trade, but also they are in fact 'in need' of such engagement.

To sum up, since import and export can increase the innovation propensity of firms (in general) and given that firms in the declining industries are assumed to (i) be able to and (ii) have more incentives to engage in import and export (stemming from their need to such engagements), it can be hypothesized that;

Hp3: Engagement in export and import is more important for innovation propensity of the firms in declining industries than the firms in other stages of ILC.

\subsection{Determinants of innovation intensity}

For those firms who become innovative, the interesting phenomenon to be studied is how much innovation, i.e. innovation intensity, they do. The classical determinant (input) of innovation intensity has been recognized as $R \& D$ investment [40]. Oslo Manual [41] extends the classical input to six investment categories (i.e. innovation inputs), such as investment in internal $R \& D$, investment in external R\&D, acquisition of machinery, and training of employees ${ }^{9}$.

The crucial point for achieving the higher innovation intensity is the concept of return on investment (here referring to the six investment categories). The argument of this paper here is that in the growing stage, the return on investment for innovation is higher in compare with later stages. This is because of lack of dominant design in the growing stage, which creates abundant rooms for innovation (especially for product innovation) [3]. This simply means firms in growing industries face higher technological opportunity conditions to innovate, lower barriers for innovative entry, and therefore higher return on investment for innovation [42] [3] [7]. However, it is worthy to note that most firms (entrants) in the growing stage are small, lack in-house resources, and presumably have difficulties to invest heavily in innovation inputs. So it is fair to say if firms in growing industries succeed to invest in innovation inputs, it is expected that they can benefit from higher proportion of return on investment (especially toward product innovation) in compare with firms in later stages of ILC.

\footnotetext{
${ }^{9}$ Oslo Manual [41] defined six investment categories (called 'innovation inputs' in this paper) for a given firm as being: internal R\&D, external R\&D, acquisition of machinery, training for employees, engagement in market introduction of innovation, and engagement in other external knowledge.
} 
On the other hand, the innovation portfolios of the firms in mature and declining industries are characterized mostly by process and organizational innovations. While innovation inputs are crucial in these stages, too, however the expected return on investment is lower in compare with growing industries, as dominant design is already achieved, barriers to innovation is higher, opportunity condition is lower, and market share of large firms is more stabilized [7]. This argument is reinforced by the empirical evidences showing that the innovation inputs rise less than proportional to size [27]. This means those small firms (occupying growing industries, based on Schumpeter Mark I) who perform R\&D investment and other types of innovation inputs tend to be more innovative than large firms (occupying mature/declining industries, based on Schumpeter Mark II) who perform the same amount of investments.

To sum up, while innovation inputs are crucial for innovation intensity (output) of firms, its role seems to be more pronounced in the growing industries in compare with later stages, basically because of higher return on investment in growing industries.

Hp4: Innovation input of the firm is more important for innovation intensity of the firms in growing industries than the firms in other stages of ILC.

\section{Empirical methods for identification of ILC stages}

Perhaps the explicit endeavor to develop an empirical tool to identify the stages of industry life cycle can be traced back to the seminal work of Gort and Klepper [42]. They used the data on annual number of producers of 46 new products from 1887-1960 in US to classify the (product) life cycle to five stages based on net entry of firms in any given product. Subsequently there have been several studies developing empirical tools for identification of the stages of given industry, product or cluster (reviewed in Appendix A). These methods are based on (again) net entry [43] [16], rate of growth in the number of the firms [44], innovation intensity together with the size (large/small) of dominant innovators [45], maturity index [17], and employment growth [46].

Some of the mentioned methods are not applicable in Sweden, as the case of this paper, because of limitation of available data. For instance, unlike US, there is no time series data capturing annual net entry available in Sweden since early $20^{\text {th }}$ century, in order to make it possible to do what Klepper has done exactly. Nevertheless, inspired by previous methods, three methods are developed in this section for the purpose of this paper, which are summarized in Table 1. 
As Karlsson and Nyström [16] note, there can be several reasons for a new plant to enter in an industry. A totally new firm might enter (greenfield entry) or an already existing firm might want to increase their production capacity, expand the geographical market, or diversify their activities. An exit is reported when the identification number disappear. This is something that happens when a plant ceases to exist (closedown exit) or when a plant totally changes its original activity to an activity that is not covered by the collection method used for this data source. An example of this is when a manufacturing plant becomes a plant involved in producing services ${ }^{10}$.

The data regard to industry dynamics used in this paper is obtained from Statistics Sweden (SCB). It covers the number of plants ${ }^{11}$ and their employments per year for all Swedish industries in 2-digit NACE code in the period of 1990 to 2004. Total number of 59 industries in 2-digit over the 15 years period provides 885 observations (i.e. number of plants/employments per year per industry over the period 1990 to 2004). Then following measures are obtained over 15 years: (i) number of positive net entry and negative net entry (i.e. net exit) per industry, (ii) average net entry/exit per industry per year, and (iii) number of employment growth (measure by Birch Index) per industry per year. These three measures are the base of three methods, reported in Table1, for classifying any given Swedish industry to fall into one of triple-based classification of the stages of industry life cycle, i.e. growing, mature, or declining, in the time of study ${ }^{12}$. The descriptions of the three methods are presented in Table1.

\section{[Table 1 about here]}

As it is shown in Table 1, the outcomes of three applied method are similar (distinctively methods two and three). The detailed classification of industries to stages of ILC based on above three methods is reported in Appendix B. Out of 59 industries, 23 industries are insensitive to the choice of ILC classification method, i.e. these industries are classified to the stages of ILC exactly the same by the three methods. For instance, 'Agriculture and hunting' classified to be 'declining'

\footnotetext{
${ }^{10}$ A firm, especially MNE, can shut down one (or several) of its plant in Sweden and start several plants in other countries (e.g. in case of outsourcing) and in fact start to grow and so the industry. Nevertheless, the industry in" Sweden" show the exit pattern and this is what this paper is concerned with, i.e. country-specific pattern of net entry/employment growth of industries "within" Sweden as a country.

${ }^{11}$ It is important to note the distinction between a plant, which refers to a production entity, and a firm, which is a legal entity. This means that the plants identification number is connected to the geographical location of the plant and therefore the identification number will not change even if firms are merging or changing owners [16]. This is an advantage in empirical analysis of this paper, since in the case of merger and acquisition the ILC classification of this paper still can be valid.

${ }^{12}$ The "rebirth" stage of ILC (as the fourth stage) is perceived in this paper as showing the same pattern as growing, hence a separate stage is not devoted for it. However, it should be acknowledged that it may not be a perfect choice, for instance, size of the firm is expected to be irrelevant to explain innovation in growing stage while it is not necessary the case in rebirth stage.
} 
by all three methods. The rest of industries (except four industries) are classified by the three methods in a way that two methods always reveal the same results and the third one has slightly different results. For instance, 'forestry and logging' is classified as a mature industry by method I and as a declining industry by method II and III.

Having 23 industries to be insensitive to the choice of ILC classification method is the indication that the three adapted methods in this paper are somehow measuring the same phenomenon, i.e. an indication for robustness of the three methods. On the other hand, there are the rest of industries which are classified slightly different by the three methods. Nevertheless, this is indeed expected, because each method measure different thing (i.e., number of positive net entry, average net entry, number of employment growth). But the important point is that although each method of ILC classification classifies the Swedish industries in slightly different way, nevertheless the estimation results of innovation models (Heckman) are the same, regardless of using which ILC classification method (estimation results are presented in section 4.2). This is indeed a robustness check showing that the arbitrary choice of ILC classification is not driving the result of this study and results are robust.

For the sake of uniqueness in the subsequent estimation of innovation model, method I is chosen for classification of ILC stages: out of 59 active Swedish industries in 2-digit NACE code, 18 sectors identified to be growing, 27 sectors to be mature, and 14 to be declining. Then, based on 2-digit NACE code of any given firm, 1058 firms identified to be in growing industries, 1591 in mature and 458 in declining industries (out of total 3108 firms in CIS4). The estimation results for method II and III are reported in Appendix D1 and D2.

\section{Empirical analysis of innovation model}

\subsection{Data and model}

The data regard to innovation model of this paper is based on the $4^{\text {th }}$ Community Innovation Survey (CIS4) for Sweden with 3309 observations ${ }^{13}$. The survey was conducted in 2005 and asked the participant firms about their innovation-related activities during 2002 to 2004. Nevertheless, the dataset is a cross-sectional one with a single point in time, i.e. 2004. The response rate was close to 70 percent, which covers both manufacturing and business service

\footnotetext{
${ }^{13}$ The $\mathrm{CIS}(4)$ is a pan-European cross-sectional survey which consists of micro-aggregated data. For an overview of a growing group of empirical studies employing CIS-data see [13].
} 
firms with ten and more employees ${ }^{14}$. CIS dataset provides interesting and new information on firm-level innovation activities, both in terms of measuring innovation itself (propensity and intensity) and also explanatory variables for innovation. In terms of the former, the survey provides the direct measure of innovation, i.e. amount of sales due to innovative products (not routine products). This measure is argued to be a superior measure compared with commonly used indirect measure of innovation, such as patent application or R\&D intensity [47] [48]. In terms of later, CIS provides interesting explanatory variables such as whether a given firm did cooperation in its innovation activities or not, and also whether the innovation activities has been persistently pursued or not. In addition, the dataset allows extending the classical innovation input (i.e. R\&D investment) to five more categories of investment (see Appendix C). This is particularly important as it is shown that $R \& D$ can work at best as part of the innovation input and it is not even the most important innovation input [48]. The information on innovation activities from CIS is supplemented with registered data on sales, physical capital, human capital, employment, export, import and corporate ownership structure from Statistics Sweden (SCB) for the firms in question ${ }^{15}$.

First by using all observations, the analysis will highlight the relative importance of determinants of the likelihood of a firm to be innovative (innovation propensity), based on the stage of ILC that the firms belong to (introduced in section 3). A given firm is perceived to be innovative in this paper if its innovation investments (input to innovation process) and its innovative sales ${ }^{16}$ (output of innovation process) are positive [19] [49] [33]. Second, for those firms who declared to be innovative, the analysis will go further and investigate the relative importance of the determinants of their 'intensity of innovation', measured as the portion of sales income due to innovate products per employee, again over ILC.

The reason for choosing such two-step estimation strategy can be summarized in three points; the first two concerning econometric issues and the last one is a theoretical issue. First, CIS data are collected in the way that it raises the selection bias [50]. The dependent variable in innovation intensity equation (portion of sales income due to innovate products per employee) is the function of, for instance, innovation inputs and doing continuous R\&D. But there are many missing values of the dependent variable, i.e. dependent variable is not observed (i.e. not selected by firms to

\footnotetext{
${ }^{14}$ The strata with 10-249 employees have a stratified random sampling with optimal allocation. All firms above 249 employees are covered.

${ }^{15}$ For the sake of merging registered data with survey data, some observations are dropped from CIS, which leaves the sample size to be 3102. There have been similar data cleaning in [33].

16 'Innovative sales' is a self-reported data by firms answering a question about the "the portion of turnover due to new/ improved products (to the market/firm) introduced during 2002-2004".
} 
answer) in those missing values. The point is that these missing values are not randomly missed and the likelihood of 'being innovative' (likelihood of innovative sales being observed) is itself the function of other underlying factors, such as ownership structure or size of the firm. Heckman [51] considers this situation as some sort of "omitted variables" and called it "selection bias", which he then corrects for such bias by means of two-steps estimation procedure ${ }^{17}$.

Second, if all explanatory variables of propensity and intensity are included in a single OLS regression, the estimates would suffer intensively from endogeneity problems. For instance the higher import and export can lead to higher innovation intensity and vice versa. It has been argued that if one instead plugs-in import and export (and other variables explaining propensity) in a probit estimates of likelihood of being innovative, the overall model would suffer less from endogeneity [50].

Third, the division of explanatory variables into two groups of propensity and intensity (equations) is motivated by the theory, too. For instance there is more theory (and related empirical evidences) attributing the engagement in international trade to the likelihood of being innovative (propensity) rather than to the intensity of innovation [50].

Therefore, and in line with Mohnen et al [19], this paper adopts a Heckman two-step estimates of innovation model, consists of two equations, where the first one is a probit equation (selection equation) determining whether a firm innovates or not. This equation is responsible for not only estimating the determinants of innovation propensity, but also generating a selection corrector variable (to be used in second equation). The second equation is output equation (corresponds to intensity), which is a linear regression explaining how much the firm innovates (conditional on being innovative). The dependent variable in the first equation, $\mathrm{y}_{1 i}$, is an innovation dummy indicating whether firm $i$ is an innovative firm or not:

$$
y_{1 i}= \begin{cases}1 & \text { if } y^{*}>0 \\ 0 & \text { if } y^{*}{ }_{1 i} \leq 0\end{cases}
$$

Where $\mathrm{y}_{1 \mathrm{i}}$ is assumed to be a latent innovation decision variable measuring the propensity to innovate for firm $\mathrm{i}$, which is generated as follows:

\footnotetext{
${ }^{17}$ To put the existence of selection bias in the other words, this paper is interested to estimate the determinants of innovation intensity, but there is only access to innovation intensity observations for those firms who declared themselves innovative. Since these self-declared innovative firms are selected non-randomly from the population, estimating the determinants of innovation intensity from this self-selected subpopulation might induce selection bias.
} 


$$
y_{1 i}^{*}=\boldsymbol{X}_{1 i} b_{1}+\boldsymbol{Z}_{1 i} \omega_{1}+u_{1 i}
$$

where $X_{1 i}$ is the vector of explanatory variables, i.e. human capital, size, and three dummies for import and export. $Z_{1 i}$ is the vector of control variables, i.e. corporate ownership structure, capital structure, and industry dummies ${ }^{18}$ (precise variable definitions is reported in Appendix C). Coefficient $b_{1}$ is a vector of parameters for interested explanatory variables to be estimated, and $u_{1 i}$ is a random error term. Equation ( $\left.1^{\prime}\right)$ is interpreted as saying that if $y^{*}{ }_{1 i}$ is positive, incentives to innovate are large enough for a given firm to actually innovate $\left(y_{1 i}=1\right)$. In practice, $y^{*}{ }_{1 i}$ is not actually observable, instead, all that can be observed is a dummy variable, $y_{1 i}$, with value 1 if a given firm select itself to be innovative $\left(y^{*}{ }_{1 i}>0\right)$ and 0 otherwise.

The dependent variable in second equation, $\mathrm{y}_{2 \mathrm{i}}$, is $(\log )$ portion of sales income due to innovative products per employee. This is a common way of measuring innovation intensity in CIS data [19] [49] [33]. The second equation of the innovation model (output equation) is expressed as follows:

$$
y_{2 i}= \begin{cases}\mathrm{y} *_{2 \mathrm{i}} & \text { if } y_{1 i}=1 \\ \text { undefined } & \text { if } y_{1 i}=0\end{cases}
$$

Where it is assumed that there is a latent variable $\mathrm{y}_{2 \mathrm{i}}$ for firm $i$ that is generated as follows:

$$
y_{2 i}^{*}=X_{2 i} b_{2}+Z_{2 i} \omega_{2}+u_{2 i}
$$

Where $X_{2 i}$ is the main explanatory variable, i.e. innovation inputs (measured as the sum of expenditures in six innovation activities). Coefficient $b_{2}$ is a vector of parameters to be estimated. $Z_{2 i}$ is the vector of control variables, i.e. size, doing continuous $R \& D$, doing cooperative innovation activities ${ }^{19}$, industry dummies, and an additional independent variable called Lambda (i.e. inverse Mills' ratio), which is generated by saving the unobserved effects in the probit estimation in order to isolate the effect of selectivity bias in the output equation [51] ${ }^{20}$. If coefficient of Lambda turns out to be significantly different from zero (see Table 2), it means $u_{1 i}$ and $u_{2 i}$ are correlated, hence selection bias indeed exists. In this case, adding this additional independent variable in the second step of the Heckman model can accommodate the potential

\footnotetext{
${ }^{18}$ The choice of these explanatory variables is restricted to the available data.

${ }^{19}$ One could include all $\boldsymbol{X}_{1 i}$ and $\boldsymbol{Z}_{1 i}$ in the $\boldsymbol{Z}_{2 i}$, too. However, additional analysis showed that most of $\boldsymbol{X}_{1 i}$ and $\boldsymbol{Z}_{1 i}$ are not appeared to be significant in the second step, and also the results for $X_{2 i}$ remained the same.

${ }^{20}$ Inverse Mills' ratio is the ratio of the probability density function to the cumulative distribution function of a distribution. In the case of Hackman 2-step, it is calculated at the point of $\boldsymbol{X}_{1 i} b_{1}+\boldsymbol{Z}_{1 i} \omega_{1}$.
} 
selection bias concerning the non-randomness of the sample (which is some sort of omitted variable bias) [51].

\subsection{Results}

Based on the stage identification of any given sector and subsequently any given firm in the data set (in section 3), it is possible to breakdown the whole sample size to three subsample of firms, i.e. firms who belongs to growing, mature and declining industries. Then, the innovation model (equation (1) and (2)) can be estimated not only for whole sample size, but also dedicatedly for firms in growing, mature, and declining industries. This is reported in Table $2^{21}$.

\section{[Table 2 about here]}

The classification of firms (and their industries) in Table 2 is based on method I of ILC classification (method I in Table 1). Lambda is always significantly different from zero; not only in all sample size, but also even after breaking down the total sample to three subsamples (growing, mature, and declining). This clearly shows the existence of selectivity bias in the sample and necessity of using Heckman's two-steps procedure.

Regard to innovation propensity columns, Human capital has a highly significant and positive effect on the probability of being innovative, which is expected. The notable point is when the sample is broken down based on the stages of ILC, such significance is only observable for the firms in growing and mature industries. However, unlike the expectation, it seems human capital is more influential on mature industries than in growing (and it is robust in all methods of ILC classifications). This implies that the null of the $1^{\text {st }}$ hypothesis cannot be rejected. Possible explanation could be with the concept of capital circulation by Harvey [52]. He emphasized that while firms (especially MNEs) together with their belonged industries become mature, they are in need to refill their (human) capital to be able to stay competitive and innovative.

Size has a highly significant and positive effect on the likelihood of being innovative, which is expected based on previous literature [22] [23] [19]. The point is when the sample is broken down based on stages of ILC, such significance is only observable for the firms in mature industries, confirming the $2^{\text {nd }}$ hypothesis. This result is again quite robust in all of three methods of ILC classification. Effect of size is insignificant in two other stages, which is in line with

\footnotetext{
${ }^{21}$ An alternative way for estimation strategy is to avoid breaking down the sample to three sub-samples, instead, always using the whole sample size by employing the interaction terms (e.g. size-growing, size-mature etc.). However, this alternative way reveals high multicollinearity issues, so it is not employed.
} 
Schumpeterian literature (Mark I). Especially in growing industries, the effect of size is insignificant in all three methods. This is also perfectly in line with Schumpeterian literature, noting that small firms have innovative advantageous in growing industries [5]. This means size does not have obvious explanatory power for explaining the innovativeness of the firms in growing industries.

Engagement in both import and export is always significant and positive; in all industries and in any stages of ILC. But if a firm is a one-way trader (only import or only export) the impact is not significant in the all sample size, growing and matures industries. This is somehow in line with other Swedish empirical evidences showing that firms engaging in both export and import (i.e. two-way traders) are more productive than one-way trader [53]. The interesting point is that declining industries are the only ones that not only two-way traders are probable to innovate more, but also even one-way trader are showing significant positive behavior in terms of being innovative. It means it does not make difference if one chooses only import dummy, or only export dummy, or both. In all cases, there is the positive and highly significant impact of engagement in import and/or export on being innovative, showing the relative importance of international trade in declining industries, i.e. confirming the $3^{\text {rd }}$ hypothesis. The results are not sensitive to the choice of ILC classification, hence robust.

Looking at innovation intensity (output) columns, innovation inputs is significant and positive in all stages, as it was expected. The interesting point is that it has its strongest effect in the growing industries, which confirms the $4^{\text {th }}$ hypothesis. Therefore, breaking down the total sample to three stages of ILC reveals that firms in growing industries are the ones who benefit more than firms in any other stages (and even more than the whole sample in average) from innovation inputs, ceteris paribus. This result is again quite robust in all of three methods of ILC classification. As already noted in the related hypothesis, this result can be explained by the stylized facts that in the growing industries there are higher opportunities and lower barriers to innovate [7], hence, there is higher return on investment in compare with other stages of industry evolution. This simply implies the relative importance of investment in innovation (innovation inputs) in the growing industries.

Among control variables, there is one robust result worthy to note. In corporate ownership structure variables, being a domestic MNE seems to have a positive impact on likelihood of being innovative for two models: (i) all sample size and (ii) growing industries. The former is in line with previous studies in Sweden [24]. The latter result is probably more novel. This could be because in growing industries there is a need for swift and effective communication between the producer with customers and suppliers (vertically-linked segments of the industrial value chain) 
and even competitors (horizontally-linked), in order to overcome the uncertainty [14]. And it is found elsewhere that such swift collaboration is more likely to happen for domestic MNEs in compare with other type of corporate ownership structures [54] [55].

Three robustness checks are performed. First, the choice of industry classification is arbitrary and may drive the results of estimations. Therefore, beside method I for ILC classifications, method II and III are also used. Nevertheless, the Heckman estimation reveals the same results (They are reported in Appendix D1 and D2). This implies that the choice of ILC classification method is not driving the results of the estimation of innovation model, which is the indication for robustness of the estimation results. Second, some studies used somewhat looser criterion for identifying the innovative firms [49], i.e. an alternative dependent variable in the first equation (with probit estimate). It is a dummy variable receiving value one only if a firm has positive share of innovative sale. This alternative variable put somewhat looser criteria for recognizing an 'innovative firm' in compare with the innovation dummy used initially, i.e. it encompass only output part and not input part of the innovation process. Nevertheless, using this alternative dependent variable, the results remain the same and also insensitive to the choice of ILC classification methods $^{22}$. The last robustness check is concerned with time-series nature of ILC classification methods versus cross-sectional nature of innovation model. There might be a risk that an industry identified to be, for example, growing over 15 years period (1990-2004), is not really showing a pattern of a growing industry in the last 2 years, where cross-sectional innovation model is estimated. Therefore, a narrower time window is used, which includes only the last 5 years (2000 to 2004). Nevertheless, almost all industries show the same pattern as they were showing already with 15 years' time window.

Overall, out of proposed four hypotheses in this paper, three of them are confirmed and one is rejected. Nevertheless, the confirmed hypotheses are in regard with both innovation propensity and innovation intensity. This means this paper highlights the relative importance of at least some of the determinants of both aspects of firm's innovative behavior (propensity and intensity). Furthermore, there is at least one confirmed hypothesis per stage of ILC.

\footnotetext{
22 The results for this robustness check are available upon a request.
} 


\section{Conclusion}

The literature suggests several determinants explaining the innovative behavior of firms. But the central question in this paper was whether these determinants are equally important or not if one takes into account meso-level context in which innovation happens, i.e. the stages of industries in which firms operate and innovate. There are number of novelties in this paper: (i) it brings together micro level (firm-level innovation studies) and meso level arguments (ILC literature) in which innovation happens, and testing them in a common empirical setting. (ii) It employs firmlevel Community Innovation Survey (CIS) data, allowing for a direct measure of innovation and a distinction between determinants of innovation propensity (probability of being innovative) and intensity ( the amount of innovation sales), respectively. (iii) It employs various established methods to empirically identify stages of industry life cycles.

The results suggest that the relative importance of the determinants of firms' innovation propensity and intensity indeed differ based on the stages of ILC. Regard to propensity, size and human capital shown to be the most influential determinants for the firms in mature industries (in compare with firms in other stages of ILC). Engagement in network of international trade is the most influential determinant for firms in the declining industries. Regard to innovation intensity, innovation inputs is the most important determinant to explain the innovation intensity of firms in growing industries. Results are robust based on various robustness checks.

All in all, this paper highlights the relative importance of the factors explaining both aspects of innovative behavior of firms, namely innovation propensity and innovation intensity, based on the stages of the industries that firms belong to. Such analysis can provide fruitful insights for firms to define their innovation strategy contingently in line with the evolution stage of the industry in which they are operating and innovating, and not only with myopia of micro dynamic of their own enterprise.

To be more specific, a task of the firm's strategic management would be first to identify which industry the firm belongs to. Second, which stages of ILC that industry belongs to. Then there are several scenarios to be considered for improving the innovation propensity/intensity of firms. First, if a given firm belongs to a growing industries (like computer and related activities), it is generally better to have offensive innovation strategy by investing in several types of innovation activities, such as internal and external R\&D, training of employees, acquisition of machinery, 
and market introduction of innovation [56 ${ }^{23}$. This is because the return on investment in innovation activities is higher in this stage in compare with other stages of ILC. Second, if a firm belongs to a mature industry (like manufacture of pulp and paper), it is better to invest in human capital. This may be achieved by recruiting high-skilled individual rather than investing heavily in training of employees. Third and finally, if a given firm belongs to a declining industry (like manufacture of office machinery), it is better to invest in exploring the international market. This would create new channels of learning from customers abroad, which eventually can enhance firm's innovation [29] [30] [31]. Such investment would be specifically helpful in the case of "disruptive innovation". As Clayton Christensen argued, a suitable approach to handle the disruptive innovation is to try to find a "new market" that values characteristics of the disruptive technology [57] and one way to find the new market is to explore the export markets, especially if domestic market is not big enough (as in the Swedish economy) or the local institutions are not favorable for introducing the disruptive innovation. Kodak is a famous counter-example which is in a declining/mature industry that faced the disruptive innovation, i.e. emergence of digital photography. Unlike its life-long competitor Fujifilm, Kodak has not been fast enough to respond to the quick change of the industry due to disruptive innovation [58]. Kodak could have accept the emergence of disruptive innovation in industry faster and accommodate it by searching for new markets (i.e. export market), if the emerging disruptive innovation did not fit to its mainstream market immediately. The investment in exploring the export market should be usually feasible for those survivors firms in declining industries (like Kodak before bankruptcy), because they are presumably large and productive enough to overcome to the associated costs of entering the export market [59]. At the end, it should be noted that this paper had a focus on the innovation 'determinants' over stages of ILC. Future research may focus on the dynamic pattern of innovation propensity versus innovation intensity themselves over stages of ILC.

\section{Acknowledgment}

Valuable comments by Ron Boschma, Martin Andersson, participants of DIMETIC 2011 session in Maastricht University, and two anonymous referees are greatly appreciated.

\footnotetext{
${ }^{23}$ Beside offensive strategy, a given firm in growing industry may also have defensive innovation strategy by trying to have incremental innovation and be a second-mover, but it may not pursue imitative or dependent strategy (e.g. licensing) [56].
} 
Appendix A: The empirical methods for identification of industry, product, or cluster life cycle- a literature review

\begin{tabular}{|c|c|c|c|c|}
\hline Author & Stages & Methodology (for life cycle segmentation) & $\begin{array}{c}\text { Data } \\
\text { characteristics }\end{array}$ & Remarks \\
\hline $\begin{array}{l}\text { Gort \& } \\
\text { Klepper } \\
(1982)\end{array}$ & $\begin{array}{c}5 \text { stages of } \\
\text { development }\end{array}$ & $\begin{array}{l}\text { - The stages are defined in terms of net entry (i.e. changes in the number of } \\
\text { producers). Stage I encompasses the interval in which the number of producers } \\
\text { in the market remains relatively small (usually between one and three) for a } \\
\text { given product. Stage II is the interval from the 'take-off' point of net entry to } \\
\text { the time that net entry decelerates drastically. Stage III is the ensuing period of } \\
\text { low or zero net entry, and Stage IV is the subsequent period of negative net } \\
\text { entry. Stage V represents the new equilibrium in the number of producers } \\
\text { (again zero net entry). } \\
\text { - The decomposition of each product into stages is done in two steps. First, for } \\
\text { a given product, intervals that clearly show the characteristics of each of the } \\
\text { five stages are identified by visual inspection of the plotted series (pre- } \\
\text { classification). This could preliminary shows that each product has reached to } \\
\text { which of } 5 \text { stages so far. Second, the remaining years - that is, those for which } \\
\text { the entry rates could have been associated with either of the two adjacent stages } \\
\text { - is then classified into four additional 'in-between' stages. Then, those in- } \\
\text { between years is allocated to one of the initial } 5 \text { stages by means of } \\
\text { 'standardization' of net entry for all years and using standard discriminant } \\
\text { analysis. }\end{array}$ & $\begin{array}{l}\text { - Used data: annual } \\
\text { number of } \\
\text { producers of } 46 \\
\text { new products } \\
\text { - Data source: } \\
\text { Thomas' Register } \\
\text { of American } \\
\text { Manufactures } \\
\text { - Period: } 1887-1981 \\
\text { - Coverage: } 46 \text { major } \\
\text { new products } \\
\text { introduced to } \\
\text { market initially } \\
\text { ranging from } 1887 \\
1960\end{array}$ & $\begin{array}{l}\text { - 'Standardization' of entry rate } \\
\text { (for each year) is done to get rid } \\
\text { of cross sectional variation in } \\
\text { entry rates. It is done by dividing } \\
\text { the value of each observation (the } \\
\text { number of producers in each } \\
\text { year) for any given product to the } \\
\text { average entry rate in pre- } \\
\text { classified stage } 2 \text { of that product } \\
\text { (stage } 2 \text { as the highest stage in } \\
\text { terms of net entry). } \\
\text { - We might ignore the second step, } \\
\text { as we are not interested on } \\
\text { historical development of } \\
\text { products. We just want to know } \\
\text { which product (industry) reaches } \\
\text { to which stage now. }\end{array}$ \\
\hline $\begin{array}{l}\text { Klepper \& } \\
\text { Graddy } \\
(1990)\end{array}$ & $\begin{array}{l}\text { Grow, } \\
\text { Decline } \\
\text { (shake out), } \\
\text { Stability }\end{array}$ & $\begin{array}{l}\text { Stage } 1 \text { ends when the number of firms reaches a peak. Stage } 2 \text { ends in the year, } \\
\text { denoted by } t * \text {, after which the average annual change in the number of producers } \\
\text { is greater than }-1.0 \% \text { of the peak number of producers in each of the following } \\
\text { periods: } \mathrm{t} * \text { to } \mathrm{t} *+5, \mathrm{t} * \text { to } \mathrm{t} *+10, \mathrm{t} * \text { to } \mathrm{t}^{*}+15, \ldots, \mathrm{t} * \text { to } \mathrm{t}^{*}+\text { the last year of } \\
\text { the product's history. Stage } 3 \text { will be the rest of the product's history. }\end{array}$ & $\begin{array}{c}\text { The same as Gort \& } \\
\text { Klepper (1982) }\end{array}$ & $\begin{array}{l}\text { This method use "cumulative } \\
\text { moving average" (as the starting } \\
\text { point, } t^{*} \text {, is fixed) to identify the } \\
\text { end of stage } 2 \text {. }\end{array}$ \\
\hline $\begin{array}{l}\text { Audretsch } \\
\quad \& \\
\text { Feldman, } \\
\text { (1996) }\end{array}$ & $\begin{array}{l}\text { Introduction, } \\
\text { growth, } \\
\text { mature, } \\
\text { declining }\end{array}$ & $\begin{array}{l}\text { Industries with high innovation intensity AND where that innovation intensity } \\
\text { tends to come from small firms are characterized as introduction stage. } \\
\text { Industries with high innovation intensity AND where that innovation intensity } \\
\text { tends to come from large firms are characterized as growth stage. Industries with } \\
\text { low innovation intensity AND where that innovative intensity tends to come from } \\
\text { large firms are characterized as mature stage. And finally, industries with low }\end{array}$ & $\begin{array}{l}\text { - Used data: } \\
\text { innovation } \\
\text { intensity and firm } \\
\text { size } \\
\text { Data source: Small } \\
\text { Business } \\
\text { Administration's }\end{array}$ & $\begin{array}{l}\text { - Innovation intensity together with } \\
\text { the size (large/small) of dominant } \\
\text { innovator is the base of this } \\
\text { method. } \\
\text { - Four-digit SIC industries into } \\
\text { these four stages of the life cycle. }\end{array}$ \\
\hline
\end{tabular}




\begin{tabular}{|c|c|c|c|c|}
\hline & & $\begin{array}{l}\text { innovation intensity AND where that innovative intensity tends to come from } \\
\text { small firms are characterized as declining stage of the life cycle. }\end{array}$ & $\begin{array}{l}\text { Innovation Data } \\
\text { Base } \\
\text { - Period: } \\
\text { - Coverage: All } \\
\text { firms in } 210 \text { four- } \\
\text { digit SIC } \\
\text { industries }\end{array}$ & $\begin{array}{l}\text { - High innovative industries: those } \\
\text { industries exhibiting innovative } \\
\text { activity in excess of the mean. } \\
\text { (Low innovative: vice versa) } \\
\text { - Small-firm innovation intensity: } \\
\text { number of innovations made by } \\
\text { firms with fewer than } 500 \\
\text { employees divided by small-firm } \\
\text { employment } \\
\text { (Large-firm innovation intensity: } \\
\text { vice versa) }\end{array}$ \\
\hline $\begin{array}{l}\text { McGahan } \\
\quad \& \\
\text { Silverman } \\
\text { (2001) }\end{array}$ & $\begin{array}{l}\text { Emerging, } \\
\text { Maturity, } \\
\text { Decline }\end{array}$ & $\begin{array}{l}\text { - A mature industry can be identified by one of following algorithm: } \\
\text { o Algorithm 1: An industry hits its maturity point in the first year in which; } \\
\text { the number of firms grows during a 3-year period at less than } 3 \% \text { of the } \\
\text { growth rate in the prior 3-year period } \\
\text { o Algorithm 2: Algorithm } 1 \text { or The first year in which the number of firms } \\
\text { declines over a 3-year period (algorithm } 2 \text { liberalize the algorithm 1) } \\
\text { o Algorithm 3: it is algorithm 2, but instead of 3-year period, it used 5-year } \\
\text { period (algorithm } 3 \text { tightens the algorithm 1) } \\
\text { - An industry hits its declining point in the first year in which the number of firms } \\
\text { during a 3-year period is less than } 97 \% \text { of the number in the prior 3-year period. } \\
\text { - Emerging industry is the interval before maturity starts }\end{array}$ & $\begin{array}{l}\text { - Used data: annual } \\
\text { number of firms } \\
\text { - Data source: Dun } \\
\text { and Bradstreet } \\
\text { Reports on } \\
\text { American Business } \\
\text { Activity } \\
\text { - Period: } 1981-1994 \\
\text { - Coverage: all firms } \\
\text { operating in a } \\
\text { specific SIC per } \\
\text { year }\end{array}$ & $\begin{array}{l}\text { - The method is based on rates of } \\
\text { growth in the numbers of firms } \\
\text { - For finding 3-year (and 5-year) } \\
\text { period in growth rate of number } \\
\text { of the firms, "simple moving } \\
\text { average" is used. }\end{array}$ \\
\hline $\begin{array}{l}\text { Karlsson } \\
\quad \& \\
\text { Nyström } \\
(2003)\end{array}$ & $\begin{array}{l}\text { Growing } \\
\text { stage, } \\
\text { Declining } \\
\text { stage }\end{array}$ & $\begin{array}{l}\text { All industries at the } 5 \text { digit SIC code level (in the manufacturing sector) were } \\
\text { allocated to one of } 6 \text { groups (because there were } 6 \text { years of study period), } \\
\text { depending upon their different patterns of net entry. Group } 1 \text { had positive net } \\
\text { entry all but one year during the studied period. Group } 2 \text { had positive net entries } \\
\text { all but two years, and so on. Group } 6 \text { is corresponding to industries that had a } \\
\text { negative net entry during the whole period. Then, Group } 1-3 \text { is regarded as } \\
\text { industries working in the earlier phases of the product life cycle and group } 4-6 \\
\text { are supposed to be declining industries. }\end{array}$ & $\begin{array}{l}\text { - Used data: entry } \\
\text { and exit in each } \\
\text { year for each 5- } \\
\text { digit code } \\
\text { - Data source: SCB } \\
\text { - Period: 1990-1996 } \\
\text { - Coverage: all } \\
\text { plants more than } 10 \\
\text { employees in } \\
\text { Swedish } \\
\text { manufacturing } \\
\text { sectors }\end{array}$ & $\begin{array}{l}\text { - Such industry segmentation is } \\
\text { done for the sake of identifying } \\
\text { the different stages of the PLC }\end{array}$ \\
\hline
\end{tabular}




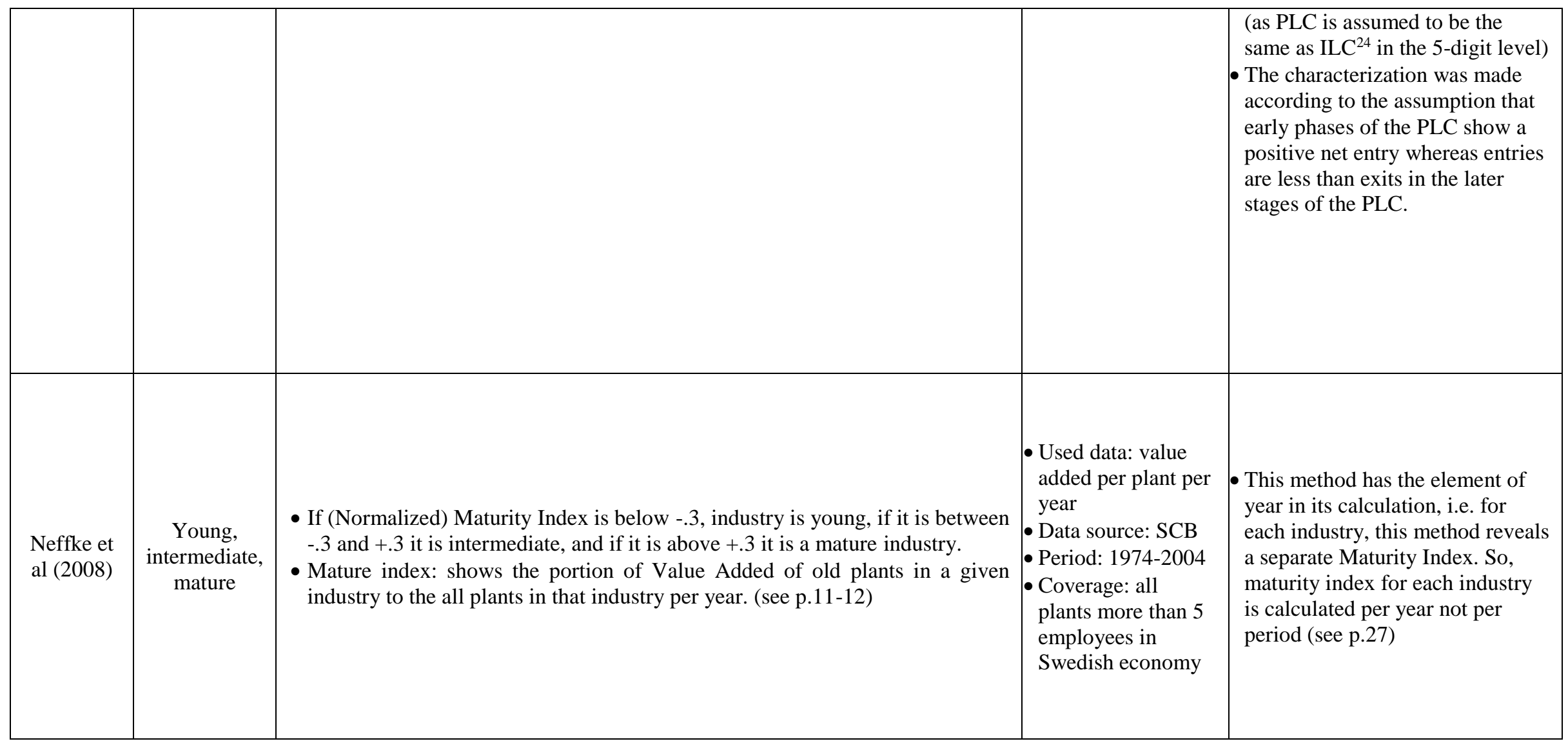

\footnotetext{
${ }^{24}$ Industry Life Cycle
} 


\begin{tabular}{|c|c|c|c|c|}
\hline $\begin{array}{c}\text { Otto \& } \\
\text { Fornahl } \\
(2010)\end{array}$ & $\begin{array}{c}\text { Emergence } \\
\text { and growth } \\
\text { Stage of } \\
\text { CLC }^{25}\end{array}$ & $\begin{array}{l}\text { The study period has been divided into } 3 \text { (almost equal) sub-periods. Then, the } \\
\text { Concentration Index (CI) (for media industry) was calculated for each sub- } \\
\text { periods and each 'Kreis' (equivalent to NUTS } 3 \text { ). A 'Kreis' is defined as an } \\
\text { emerging cluster (in media industry) if CI<0 for one sub-period and also above } \\
1 \text { in the subsequent sub-period. A growing cluster is a 'Kreis' that has CI }>1 \text { and } \\
\text { also shows the Birch Index in the fourth highest quadrant. }\end{array}$ & $\begin{array}{l}\text { - Used data: annual } \\
\text { number of firms } \\
\text { and employment } \\
\text { - Data source: } \\
\text { Historic } \\
\text { Employment } \\
\text { Database } \\
\text { - Period: 1980-2007 } \\
\text { - Coverage: all } \\
\text { plants in western } \\
\text { German media } \\
\text { industry }\end{array}$ & $\begin{array}{l}\text { - This method rely on the choice of } \\
\text { sub-period division (however } \\
\text { unclear how to choose those sub- } \\
\text { period) } \\
\text { - This method cannot identify the } \\
\text { emerging cluster in the 1st sub- } \\
\text { period } \\
\text { - Picking fourth highest quadrant } \\
\text { in Birch Index is an arbitrary } \\
\text { choice } \\
\text { - Some 'Kreis' are identified to be } \\
\text { "growing" in sub-period } 2 \text {, but it } \\
\text { is unclear what are they in sub- } \\
\text { period } 1 \text { and even } 3 \text {. }\end{array}$ \\
\hline
\end{tabular}

\footnotetext{
${ }^{25}$ Cluster Life Cycle
} 
Appendix B- Classification of All Swedish industries to stages of Industry Life Cycle

\begin{tabular}{|c|c|c|c|c|c|}
\hline \multirow[t]{2}{*}{ \# } & \multirow{2}{*}{$\begin{array}{c}\text { NAC } \\
\mathbf{E}\end{array}$} & \multirow{2}{*}{ Industry } & \multicolumn{3}{|c|}{$\begin{array}{c}\text { Classificatio } \\
\text { n methods }\end{array}$} \\
\hline & & & $\mathbf{I}$ & II & III \\
\hline 1 & 1 & Agriculture, hunting and related service activities & $\mathrm{D}$ & $\mathrm{D}$ & $\mathrm{D}$ \\
\hline 2 & 2 & Forestry, logging and related service activities & M & $\mathrm{D}$ & $\mathrm{D}$ \\
\hline 3 & 5 & Fishing, operation of fish hatcheries and fish farms & $\mathrm{G}$ & $\mathrm{D}$ & M \\
\hline 4 & 10 & Mining of coal and lignite; extraction of peat & $\mathrm{D}$ & M & M \\
\hline 5 & 11 & Extraction of crude petroleum and natural gas & $\mathrm{D}$ & $\mathrm{M}$ & M \\
\hline 6 & 13 & Mining of metal ores & M & M & M \\
\hline 7 & 14 & Other mining and quarrying & $\mathrm{D}$ & $\mathrm{D}$ & M \\
\hline 8 & 15 & Manufacture of food products and beverages & M & $\mathrm{D}$ & $\mathrm{D}$ \\
\hline 9 & 16 & Manufacture of tobacco products & $\mathrm{D}$ & M & M \\
\hline 10 & 17 & Manufacture of textiles & M & M & $\mathrm{D}$ \\
\hline 11 & 18 & Manufacture of wearing apparel; dressing and dyeing of fur & $\mathrm{D}$ & $\mathrm{D}$ & $\mathrm{D}$ \\
\hline 12 & 19 & Tanning and dressing of leather; manufacture of luggage, handbags & $\mathrm{D}$ & M & M \\
\hline 13 & 20 & Manufacture of wood and of products of wood and cork, except furniture & G & $\mathrm{D}$ & $\mathrm{D}$ \\
\hline 14 & 21 & Manufacture of pulp, paper and paper products & M & M & $\mathrm{D}$ \\
\hline 15 & 22 & Publishing, printing and reproduction of recorded media & $\mathrm{D}$ & $\mathrm{D}$ & $\mathrm{D}$ \\
\hline 16 & 23 & Manufacture of coke, refined petroleum products and nuclear fuel & M & M & M \\
\hline 17 & 24 & Manufacture of chemicals and chemical products & M & M & $\mathrm{G}$ \\
\hline 18 & 25 & Manufacture of rubber and plastic products & M & $\mathrm{D}$ & $\mathrm{D}$ \\
\hline 19 & 26 & Manufacture of other non-metallic mineral products & M & $\mathrm{D}$ & $\mathrm{D}$ \\
\hline 20 & 27 & Manufacture of basic metals & M & M & $\mathrm{M}$ \\
\hline 21 & 28 & Manufacture of fabricated metal products, except machinery and equipment & M & $\mathrm{D}$ & $\mathrm{D}$ \\
\hline 22 & 29 & Manufacture of machinery and equipment n.e.c. & M & $\mathrm{D}$ & $\mathrm{D}$ \\
\hline 23 & 30 & Manufacture of office machinery and computers & $\mathrm{D}$ & $\mathrm{D}$ & $\mathrm{D}$ \\
\hline 24 & 31 & Manufacture of electrical machinery and apparatus n.e.c. & M & $\mathrm{D}$ & $\mathrm{D}$ \\
\hline 25 & 32 & Manufacture of radio, television and communication equipment and apparatus & M & M & M \\
\hline 26 & 33 & Manufacture of medical, precision and optical instruments, watches and clocks & M & M & M \\
\hline 27 & 34 & Manufacture of motor vehicles, trailers and semi-trailers & G & M & G \\
\hline 28 & 35 & Manufacture of other transport equipment & M & M & $\mathrm{D}$ \\
\hline 29 & 36 & Manufacture of furniture; manufacturing n.e.c. & G & M & $\mathrm{G}$ \\
\hline 30 & 37 & Recycling & G & M & M \\
\hline 31 & 40 & Electricity, gas, steam and hot water supply & M & G & M \\
\hline 32 & 41 & Collection, purification and distribution of water & $\mathrm{D}$ & $\mathrm{D}$ & M \\
\hline 33 & 45 & Construction & G & M & $\mathrm{D}$ \\
\hline 34 & 50 & Sale, maintenance and repair of motor vehicles and motorcycles & M & $\mathrm{D}$ & M \\
\hline 35 & 51 & Wholesale trade and commission trade, except of motor vehicles and motorcycles & M & $\mathrm{D}$ & $\mathrm{D}$ \\
\hline 36 & 52 & Retail trade, except of motor vehicles and motorcycles; repair of household goods & M & $\mathrm{D}$ & M \\
\hline 37 & 55 & Hotels and restaurants & G & G & G \\
\hline 38 & 60 & Land transport; transport via pipelines & $\mathrm{D}$ & $\mathrm{D}$ & $\mathrm{D}$ \\
\hline 39 & 61 & Water transport & $\mathrm{G}$ & $\mathrm{M}$ & $\mathrm{M}$ \\
\hline 40 & 62 & Air transport & G & M & M \\
\hline
\end{tabular}




\begin{tabular}{|c|c|l|c|c|c|}
\hline 41 & 63 & Supporting and auxiliary transport activities; activities of travel agencies & M & G & G \\
\hline 42 & 64 & Post and telecommunications & D & D & D \\
\hline 43 & 65 & Financial intermediation, except insurance and pension funding & D & D & D \\
\hline 44 & 66 & Insurance and pension funding, except compulsory social security & M & M & M \\
\hline 45 & 67 & Activities auxiliary to financial intermediation & G & G & G \\
\hline 46 & 70 & Real estate activities & M & G & G \\
\hline 47 & 71 & Renting of machinery and equipment without operator and of household goods & G & D & M \\
\hline 48 & 72 & Computer and related activities & G & G & G \\
\hline 49 & 73 & Research and development & G & G & G \\
\hline 50 & 74 & Other business activities & G & G & G \\
\hline 51 & 75 & Public administration and defense; compulsory social security & M & D & G \\
\hline 52 & 80 & Education & G & G & G \\
\hline 53 & 85 & Health and social work & G & D & D \\
\hline 54 & 90 & Sewage and refuse disposal, sanitation and similar activities & M & M & M \\
\hline 55 & 91 & Activities of membership organizations n.e.c. & M & D & M \\
\hline 56 & 92 & Recreational, cultural and sporting activities & G & G & G \\
\hline 57 & 93 & Other service activities & G & G & G \\
\hline 58 & 95 & Activities of households as employers of domestic staff & D & M & M \\
\hline 59 & 99 & Extra-territorial organizations and bodies & M & M & M \\
\hline
\end{tabular}

Notes:

a. I, II, II are the three adopted methods to classify the industries (see Table 1).

b. G stands for growing, $\mathrm{M}$ for mature, and $\mathrm{D}$ for declining industry.

c. 23 industries are insensitive to the choice of ILC classification method, i.e. these industries are classified to the stages of ILC exactly the same by the three methods.

d. 32 industries are classified by the three methods in a way that two methods always reveal the same results and the third one has slightly different results.

e. Only 4 industries are classified in a non-homogenous way by the three methods. 
Appendix C- Variable definition

\section{Dependent Variables (DVs):}

(1) "Innovation propensity": it is a dummy with value 1 when a firm is innovative, 0 otherwise during 2002-2004. A firm is perceived as innovative in this paper if its innovation investments and its innovative sales are positive during 2002-2004.

(2) "Innovation intensity" is the (log) portion of sales income due to innovative products per employee during 2002-2004 ${ }^{26}$ (only observable for innovative firms).

\begin{tabular}{|c|c|c|}
\hline \multicolumn{2}{|r|}{ Variables } & Measures \\
\hline DVs & \multicolumn{2}{|l|}{ Explanatory variables } \\
\hline \multirow{6}{*}{ 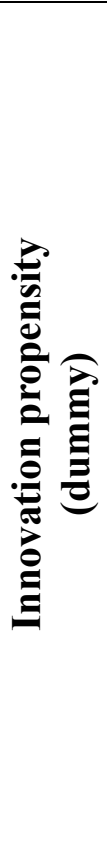 } & Size & Number of employees in $2004(\log )$ \\
\hline & Human capital & $\begin{array}{l}\text { Fraction of employees with university education of at least } 3 \text { years in } \\
2004\end{array}$ \\
\hline & $\begin{array}{l}\text { - Import } \\
\text { - Export } \\
\text { - Import and Export }\end{array}$ & $\begin{array}{l}\text { - Importer in } 2004 \text { (dummy) } \\
\text { - Exporter in } 2004 \text { (dummy) } \\
\text { - Both importer and exporter in } 2004 \text { (dummy) }\end{array}$ \\
\hline & \multicolumn{2}{|l|}{ Control variables } \\
\hline & $\begin{array}{l}\text { - Uninational firm } \\
\text { - Domestic MNE } \\
\text { - Foreign MNE } \\
\text { - Non-Affiliate }\end{array}$ & $\begin{array}{l}\text { Domestically-owned firm belonging to a group with only } \\
\text { - Swedish affiliates (dummy) } \\
\text { Domestically-owned firm belonging to a group with foreign } \\
\text { affiliates (dummy) } \\
\text { - Foreign-owned firms (belonging to a group) (dummy) } \\
\text { Domestically-owned firm without affiliates (dummy) (as } \\
\text { reference group) }\end{array}$ \\
\hline & Capital structure & $\begin{array}{l}1 \text { if (long term debt }+ \text { short term debt }) /(\text { long term debt }+ \text { short term } \\
\text { debt }+ \text { equity })>0,0 \text { otherwise in } 2004^{27}\end{array}$ \\
\hline \multirow{5}{*}{ 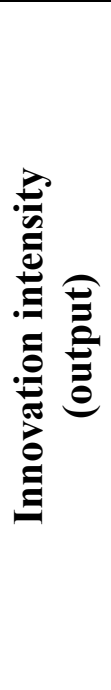 } & \multicolumn{2}{|l|}{ Explanatory variables } \\
\hline & Innovation inputs & $\begin{array}{l}\text { Innovation investment per employees }(\log ) \text {. Innovation investment is } \\
\text { the sum of following expenditures during 2002-2004: } \\
\text { - Engagement in intramural R\&D } \\
\text { - Engagement in extramural R\&D } \\
\text { - Engagement in acquisition of machinery } \\
\text { - Engagement in other external knowledge } \\
\text { - Engagement in training } \\
\text { - Engagement in market introduction of innovation }\end{array}$ \\
\hline & \multicolumn{2}{|l|}{ Control variables } \\
\hline & Continuous $R \& D$ & 1 if firm performed continuous $R \& D$ during 2002-2004, 0 otherwise \\
\hline & Cooper. inno. activit. & $\begin{array}{l}1 \text { if firm performed cooperative innovation activities during 2002- } \\
2004,0 \text { otherwise }\end{array}$ \\
\hline
\end{tabular}

\footnotetext{
${ }^{26}$ It is calculated as: "portion of sales due to innovative products" (a self-reported data by firms in CIS) multiplied by "total turnover of firm during 2002-2004", divided by "number of employees".

${ }^{27}$ Capital structure $(C S)$ is supposed to capture the financial situation of the firm. The higher the capital structure the more indebted the firm.
} 
Appendix D1- Heckman two-steps estimates of the innovation model, over the stages of ILC (Based on method II of ILC classification)

\section{Growing indust. Mature indust. Declining indust.}

\begin{tabular}{|c|c|c|c|c|c|c|}
\hline Variables & $\begin{array}{l}\text { Innovation } \\
\text { propensity }\end{array}$ & $\begin{array}{c}\text { Innovation } \\
\text { intensity }\end{array}$ & $\begin{array}{l}\text { Innovation } \\
\text { propensity }\end{array}$ & $\begin{array}{l}\text { Innovation } \\
\text { intensity }\end{array}$ & $\begin{array}{l}\text { Innovation } \\
\text { propensity }\end{array}$ & $\begin{array}{c}\text { Innovation } \\
\text { intensity }\end{array}$ \\
\hline Human capital & $\begin{array}{l}1.326 * * * \\
(8.28 \mathrm{e}-08)\end{array}$ & & $\begin{array}{l}1.555 * * * \\
(0.000150)\end{array}$ & & $\begin{array}{l}1.345 * * * \\
(2.94 \mathrm{e}-05)\end{array}$ & \\
\hline Size & $\begin{array}{l}0.0252 \\
(0.542)\end{array}$ & $\begin{array}{c}0.00683 \\
(0.918)\end{array}$ & $\begin{array}{l}0.138^{* * * *} \\
(0.00117)\end{array}$ & $\begin{array}{l}0.0611 \\
(0.222)\end{array}$ & $\begin{array}{c}0.109 * * * \\
(0.000749)\end{array}$ & $\begin{array}{l}0.0165 \\
(0.745)\end{array}$ \\
\hline Export & $\begin{array}{l}0.0116 \\
(0.960)\end{array}$ & & $\begin{array}{l}-0.465^{*} \\
(0.0934)\end{array}$ & & $\begin{array}{c}0.519 * * * \\
(0.000366)\end{array}$ & \\
\hline Import & $\begin{array}{l}-0.143 \\
(0.344)\end{array}$ & & $\begin{array}{l}-0.392 \\
(0.128)\end{array}$ & & $\begin{array}{l}0.488 * * * \\
(0.00118)\end{array}$ & \\
\hline Import and export & $\begin{array}{c}0.525 * * * \\
(0.000257)\end{array}$ & & $\begin{array}{c}0.351^{*} \\
(0.0509)\end{array}$ & & $\begin{array}{l}0.713 * * * \\
(1.39 \mathrm{e}-09)\end{array}$ & \\
\hline Uninational firm & $\begin{array}{l}0.232 * \\
(0.0944)\end{array}$ & & $\begin{array}{c}-0.000696 \\
(0.996)\end{array}$ & & $\begin{array}{l}0.0564 \\
(0.564)\end{array}$ & \\
\hline Domestic MNE & $\begin{array}{l}0.340 * * \\
(0.0380)\end{array}$ & & $\begin{array}{l}-0.0373 \\
(0.809)\end{array}$ & & $\begin{array}{l}0.267 * * \\
(0.0269)\end{array}$ & \\
\hline Foreign MNE & $\begin{array}{l}-0.0597 \\
(0.731)\end{array}$ & & $\begin{array}{l}-0.112 \\
(0.482)\end{array}$ & & $\begin{array}{c}0.149 \\
(0.233)\end{array}$ & \\
\hline Capital structure & $\begin{array}{c}0.331 \\
(0.166)\end{array}$ & & $\begin{array}{l}0.0191 \\
(0.931)\end{array}$ & & $\begin{array}{c}0.00398 \\
(0.981)\end{array}$ & \\
\hline Innovation inputs & & $\begin{array}{l}0.284 * * * \\
(1.60 \mathrm{e}-08)\end{array}$ & & $\begin{array}{l}0.177 * * * \\
(6.60 \mathrm{e}-05)\end{array}$ & & $\begin{array}{c}0.161 * * * \\
(1.33 \mathrm{e}-05)\end{array}$ \\
\hline Continuous R\&D & & $\begin{array}{l}-0.271 \\
(0.187)\end{array}$ & & $\begin{array}{l}0.0929 \\
(0.549)\end{array}$ & & $\begin{array}{c}0.118 \\
(0.359)\end{array}$ \\
\hline $\begin{array}{l}\text { Cooperative } \\
\text { innovation activities }\end{array}$ & & $\begin{array}{l}-0.172 \\
(0.366)\end{array}$ & & $\begin{array}{c}0.216 \\
(0.134)\end{array}$ & & $\begin{array}{r}-0.0615 \\
(0.603)\end{array}$ \\
\hline Lambda & & $\begin{array}{l}0.400 * \\
(0.0994)\end{array}$ & & $\begin{array}{l}0.266 \\
(0.337)\end{array}$ & & $\begin{array}{l}-0.525^{* *} \\
(0.0104)\end{array}$ \\
\hline Constant & $\begin{array}{c}14.13 * * * \\
(0.000)\end{array}$ & $\begin{array}{c}-1.511 * * * \\
(0.000)\end{array}$ & $\begin{array}{c}11.13 * * * \\
(0.000547)\end{array}$ & $\begin{array}{l}-1.604 * * \\
(0.0159)\end{array}$ & $\begin{array}{c}12.07 * * * \\
(0.000)\end{array}$ & $\begin{array}{l}-6.449 \\
(0.970)\end{array}$ \\
\hline Total Observation & 770 & & 814 & & 1518 & \\
\hline Uncensored Obs. & & 253 & & 346 & & 516 \\
\hline
\end{tabular}

\section{Notes:}

a. The table reports two-stage Heckman selection estimates. The first step estimates the equation (1) with dependent variable of innovation dummy (correspond to innovation propensity). This is for the all sample size. The Second step estimates the equation (2) with dependent variable of innovation output (correspond to intensity). This is only for innovative firms.

b. The ILC classification is based on $2^{\text {nd }}$ method of ILC classification (proposed in section 3 ).

c. All models include one set of industry indicators (dummies) to control for sector heterogeneity, which is not reported in the table. 
Appendix D2- Heckman two-steps estimates of the innovation model, over the stages of ILC (Based on method III of ILC classification)

\section{Growing indust. Mature indust. Declining indust.}

\begin{tabular}{|c|c|c|c|c|c|c|}
\hline Variables & $\begin{array}{l}\text { Innovation } \\
\text { propensity }\end{array}$ & $\begin{array}{c}\text { Innovation } \\
\text { intensity }\end{array}$ & $\begin{array}{l}\text { Innovation } \\
\text { propensity }\end{array}$ & $\begin{array}{c}\text { Innovation } \\
\text { intensity }\end{array}$ & $\begin{array}{l}\text { Innovation } \\
\text { propensity }\end{array}$ & $\begin{array}{c}\text { Innovation } \\
\text { intensity }\end{array}$ \\
\hline Human capital & $\begin{array}{c}1.367 * * * \\
(4.07 \mathrm{e}-09)\end{array}$ & & $\begin{array}{l}1.767 * * * \\
(0.00197)\end{array}$ & & $\begin{array}{l}1.331 * * * \\
(1.60 \mathrm{e}-05)\end{array}$ & \\
\hline Size & $\begin{array}{l}0.0499 \\
(0.151)\end{array}$ & $\begin{array}{l}0.0539 \\
(0.262)\end{array}$ & $\begin{array}{l}0.158^{* *} \\
(0.0260)\end{array}$ & $\begin{array}{l}0.0945 \\
(0.267)\end{array}$ & $\begin{array}{c}0.116 * * * \\
(0.000132)\end{array}$ & $\begin{array}{c}0.00468 \\
(0.921)\end{array}$ \\
\hline Export dummy & $\begin{array}{l}-0.174 \\
(0.367)\end{array}$ & & $\begin{array}{l}-0.293 \\
(0.468)\end{array}$ & & $\begin{array}{c}0.519 * * * \\
(0.000350)\end{array}$ & \\
\hline Import dummy & $\begin{array}{l}-0.177 \\
(0.214)\end{array}$ & & $\begin{array}{l}-0.621^{*} \\
(0.0774)\end{array}$ & & $\begin{array}{l}0.460 * * * \\
(0.00163)\end{array}$ & \\
\hline Import and export & $\begin{array}{l}0.442 * * * \\
(0.000443)\end{array}$ & & $\begin{array}{c}0.127 \\
(0.614)\end{array}$ & & $\begin{array}{c}0.788 * * * \\
(0.000)\end{array}$ & \\
\hline Uninational firm & $\begin{array}{l}0.193^{*} \\
(0.0997) \\
\end{array}$ & & $\begin{array}{l}0.0438 \\
(0.842) \\
\end{array}$ & & $\begin{array}{l}0.0288 \\
(0.756) \\
\end{array}$ & \\
\hline Domestic MNE & $\begin{array}{l}0.291 * * \\
(0.0317)\end{array}$ & & $\begin{array}{c}0.136 \\
(0.579)\end{array}$ & & $\begin{array}{c}0.161 \\
(0.152)\end{array}$ & \\
\hline Foreign MNE & $\begin{array}{l}0.0577 \\
(0.683)\end{array}$ & & $\begin{array}{l}-0.210 \\
(0.415)\end{array}$ & & $\begin{array}{l}0.0743 \\
(0.524)\end{array}$ & \\
\hline Capital structure & $\begin{array}{c}0.244 \\
(0.216)\end{array}$ & & $\begin{array}{l}-0.199 \\
(0.576)\end{array}$ & & $\begin{array}{l}0.0416 \\
(0.793)\end{array}$ & \\
\hline Innovation inputs & & $\begin{array}{l}0.242 * * * \\
(3.25 \mathrm{e}-09)\end{array}$ & & $\begin{array}{l}0.171 * * \\
(0.0478)\end{array}$ & & $\begin{array}{c}0.165 * * * \\
(8.91 \mathrm{e}-07)\end{array}$ \\
\hline Continuous R\&D & & $\begin{array}{r}-0.0650 \\
(0.676)\end{array}$ & & $\begin{array}{l}0.0388 \\
(0.903)\end{array}$ & & $\begin{array}{l}0.0705 \\
(0.547)\end{array}$ \\
\hline $\begin{array}{l}\text { Cooperative } \\
\text { innovation activities }\end{array}$ & & $\begin{array}{r}-0.0651 \\
(0.651)\end{array}$ & & $\begin{array}{l}0.0551 \\
(0.843)\end{array}$ & & $\begin{array}{l}0.0244 \\
(0.823)\end{array}$ \\
\hline Lambda & & $\begin{array}{l}0.258 \\
(0.222)\end{array}$ & & $\begin{array}{c}0.386 \\
(0.333)\end{array}$ & & $\begin{array}{l}-0.566^{* * * *} \\
(0.00456)\end{array}$ \\
\hline Constant & $\begin{array}{c}14.13 * * * \\
(0.000)\end{array}$ & $\begin{array}{c}-1.511 * * * \\
(0.000)\end{array}$ & $\begin{array}{c}11.13 * * * \\
(0.000547)\end{array}$ & $\begin{array}{l}-1.604 * * \\
(0.0159)\end{array}$ & $\begin{array}{c}12.07 * * * \\
(0.000)\end{array}$ & $\begin{array}{l}-6.449 \\
(0.970)\end{array}$ \\
\hline Total Observation & 1054 & & 373 & & 1675 & \\
\hline $\begin{array}{l}\text { Uncensored Obs. } \\
\text { p-values in parenthes }\end{array}$ & $k * \mathrm{p}<0.0$ & $\frac{395}{* \mathrm{p}<0.05}$ & $<0.1$ & 124 & & 596 \\
\hline
\end{tabular}

\section{Notes:}

a. The table reports two-stage Heckman selection estimates. The first step estimates the equation (1) with dependent variable of innovation dummy (correspond to innovation propensity). This is for the all sample size. The Second step estimates the equation (2) with dependent variable of innovation output (correspond to intensity). This is only for innovative firms.

b. The ILC classification is based on $3^{\text {rd }}$ method of ILC classification (proposed in section 3).

c. All models include one set of industry indicators (dummies) to control for sector heterogeneity, which is not reported in the table. 


\section{Bibliography}

[1] J. M. Utterback and W. J. Abernathy, "A dynamic model of process and product innovation," Omega, vol. 3, no. 6, pp. 639-656, 1975.

[2] R. Agarwal and M. Gort, "The Evolution of Markets and Entry, Exit and Survival of Firms," The Review of Economics and Statistics, vol. 78, no. 3, pp. 489-498, 1996.

[3] S. Klepper, "Entry, Exit, Growth, and Innovation over the Product Life Cycle," The American Economic Review, vol. 86, no. 3, pp. 562-583, 1996.

[4] S. Klepper, "Industry Life Cycles," Industrial and corporate change, vol. 6, pp. 145-181, 1997.

[5] Z. Acs and D. Audretsch, "Innovation, Market Structure, and Firm Size," The Review of Economics and Statistics, vol. 69, no. 4, pp. 567-574, 1987.

[6] G. Dosi and R. R. Nelson, "An introduction to evolutionary theories in economics," Journal of evolutionary economics, vol. 4, pp. 153-172, 1994.

[7] F. Malerba and L. Orsenigo, "Technological Regimes and Sectoral Patterns of Innovative Activities," Industrial and corporate change, vol. 6, no. 1, pp. 83-117, 1997.

[8] R. R. Nelson and S. G. Winter, An Evolutionary Theory of Economic Change, Cambridge: Harvard University Press, 1982.

[9] M. F., "Sectoral systems: how and why innovation differs across sectors," in The Oxford Handbook of Innovation, Oxford, Oxford University Press, 2005, pp. 380-406.

[10] A. P. Bartel and F. R. Lichtenberg, "The comparative advantage of educated workers in implementing new technology," Review of Economics and Statistics, vol. 69, p. 1-11, 1987.

[11] W. Cohen and D. Levinthal, "Absorptive Capacity: A New Perspective on Learning and Innovation," Administrative science quarterly, vol. 35, no. 1, pp. 128-152, 1990.

[12] B. Crepon, E. Duguet and J. Mairesse, "Research investment, innovation and productivity: An econometric analysis," Economics of Innovation and New Technology, vol. 7, no. 2, pp. 115-158, 1998.

[13] B. H. Hall and J. Mairesse, "Empirical studies of innovation in the knowledge-driven economy," Economics of Innovation \& New Technology, vol. 15, no. 4/5, pp. 289-299, 2006.

[14] R. Vernon, "International Investment and International Trade in the Product Cycle," The Quarterly Journal of Economics, vol. 2, p. 190-207, 1966. 
[15] S. Hirsch, Location of Industry and International Competitiveness, Oxford: Oxford University Press., 1967.

[16] C. Karlsson and K. Nyström, "Exit and Entry Over the Product Life Cycle: Evidence from the Swedish Manufacturing Industry," Small Business Economics, vol. 21, p. 135-144, 2003.

[17] F. Neffke, M. Svensson Henning, R. Boschma, K. Lundquist and L. Olander, "Who Needs Agglomeration? Varying Agglomeration Externalities and the Industry Life Cycle," Papers in Evolutionary Economic Geography (PEEG), pp. 1-33, 2008.

[18] A. Potter and H. D. Watts, "Evolutionary agglomeration theory: increasing returns, diminishing returns, and the industry life cycle," Journal of Economic Geography, vol. 11, no. 3, pp. 417-455, 2011.

[19] P. Mohnen, J. Mairesse and M. Dagenais, "Innovativity; A comparison across seven European countries," Economics of Innovation and New Technology, vol. 15, no. 4/5, pp. 391-413, 2006.

[20] W. S. Comanor, "Market Structure, Product Differentiation and Industrial Research," Quarterly Journal of Economics, vol. 81, pp. 639-657, 1967.

[21] F. M. Scherer, "Size of Firm, Oligopoly and Research: A Comment," Canadian Journal of Economics and Political Science, vol. 31, pp. 256-266, 1965.

[22] P. Patel and K. Pavitt, "Patterns of Technological Activity: their Measurement and Interpretation," in Handbook of the Economics of Innovation and Technological Change, Oxford, Blackwell, 1995, p. 14-52.

[23] N. Janz, H. Lööf and B. Peters, "Innovation and Productivity in German and Swedish Manufacturing Firms: Is there a Common Story?," Problems \& perspectives in management, vol. 2, pp. 184-204, 2004.

[24] M. Andersson and H. Lööf, "Small business innovation: firm level evidence from Sweden," Journal of Technology Transfer, pp. DOI: 10.1007/s10961-011-9216-9, 2011.

[25] K. Pavitt and S. Wald, The Conditions for Success in Technological Innovation, Paris: OECD, 1971.

[26] W. M. Cohen and S. Klepper, "Firm Size and the Nature of Innovation within Industries: The Case of Process and Product R\&D," The Review of Economics and Statistics, vol. 78, no. 2, pp. 232-243, 1996.

[27] M. Fritsch and M. Meschede, "Product Innovation, Process Innovation, and Size," Review ofIndustrial Organization, vol. 19, pp. 335-350, 2001.

[28] W. Keller, "International technology diffusion," Journal of Economic Literature, vol. 42, no. 3, pp. 752-782, 2004. 
[29] S. Clerides, S. Lach and J. Tybout, "Is learning by exporting important? Micro-dynamic evidence from Colombia, Mexico, and Morocco," Quarterly Journal of Economics, vol. 113, pp. 903-947, 1998.

[30] D. Castellani, "Export Behaviour and Productivity Growth: Evidence from Italian Manu-facturing Firms," Review of World Economics, vol. 138, no. 4, pp. 605-628, 2002.

[31] M. Andersson and H. Lööf, "Learning-by-Exporting Revisited: The Role of Intensity and Persistence," The Scandinavian Journal of Economics, vol. 111, no. 4, p. 893-916, 2009.

[32] R. Acharya and W. Keller, "Technology Transfer through Imports," NBER Working Paper Series 13086, 2007.

[33] H. Lööf, "Technology Spillovers and Innovation-The Importance of Domestic and Foreign Sources," in Determinants of Innovative Behavior, Basingstoke, Palgrave Macmillan, 2008.

[34] H. Lööf and M. Andersson, "Imports, Productivity and Origin Markets: The Role of Knowledgeintensive Economies," The World Economy, vol. 33, no. 3, p. 458-481, 2010.

[35] H. Bathelt, A. Malmberg and P. Maskell, "Clusters and knowledge: Local buzz, global pipelines and the process of knowledge creation," Progress in Human Geography, vol. 28, no. 1, p. 31_56, 2004.

[36] A. B. Bernard and J. Wagner, "Exports and Success in German Manufacturing," REVIEW OF WORLD ECONOMICS, vol. 133, no. 1, pp. 134-157, 1997.

[37] A. B. Bernard and J. B. Jensen, "Exceptional exporter performance: cause, effect, or both?," Journal of International Economics, vol. 47, no. 1, pp. 1-25, 1999.

[38] J. N. H. Britton, "Network structure of an industrial cluster: electronics in Toronto," Environment and Planning A, vol. 35, pp. 983-1006, 2003.

[39] R. Blundell, R. Griffith and J. v. Reenen, "Market Share, Market Value and Innovation in a Panel of British Manufacturing Firms," Review of Economic Studies, vol. 66, pp. 529-554, 1999.

[40] Z. Griliches, " Issues in Assessing the Contribution of R\&D to Productivity Growth," Bell Journal of Economics, vol. 10 , no. 1, p. 92-116, 1979.

[41] OECD, "Oslo Manual: guidelines for collecting and interpreting innovation data," OECD and Eurostat, Paris, 2005.

[42] M. Gort and S. Klepper, "Time Paths in the Diffusion of Product Innovations," Economic Journal, vol. 92, p. 630-653, 1982.

[43] S. Klepper and E. Graddy, "The Evolution of New Industries and the Determinants of Market Structure," The RAND Journal of Economics, vol. 21, no. 1, pp. 27-44, 1990. 
[44] A. M. McGahan and B. S. Silverman, "How does innovative activity change as industries mature?," International Journal of Industrial Organization, vol. 19, p. 1141-1160, 2001.

[45] D. B. Audretsch and M. P. Feldman, "Innovative clusters and the industry life cycle," Review of Industrial Organization, vol. 11, p. 253-273, 1996.

[46] A. Otto and D. Fornahl, "Origins of human capital in clusters: regional, industrial and academic transitions in media clusters in Germany," in Emerging Clusters: Theoretical, Empirical and Politcal Perspectives on the Initial Stage of Cluster Evolution, Edward Elgar publishing, Inc., 2010, pp. 99-139.

[47] A. Kleinknecht, K. Van Montfort and E. Brouwer, "The Non-Trivial Choice between Innovation Indicators," Economics of Innovation and New Technology, vol. 11, no. 2, pp. 109-121, 2002.

[48] K. Smith, "Measuring innovation," in The Oxford handbook of innovation, Oxford, Oxford University Press, 2005, pp. 148-179.

[49] H. Lööf and A. Heshmati, "On the relationship between innovation and performance: A sensitivity analysis," Economics of Innovation and New Technology, vol. 15, no. 4/5, pp. 317344, 2006.

[50] J. Mairesse and P. Mohnen, "Using innovation surveys for econometric analysis," in Handbook of the Economics of Innovation Vol. II, London, Burlington Academic Press, 2010, pp. 11291155 .

[51] J. Heckman, "Sample Selection Bias as a Specification Error," Econometrica, vol. 47, p. 153-161, 1979.

[52] D. Harvey, The Limits to Capital, Oxford, England: Blackwell, 1982.

[53] M. Andersson, H. Lööf and S. Johansson, "Productivity and International Trade: Firm Level Evidence from a Small Open Economy," Review of World Economics, vol. 144, no. 4, pp. 774$801,2008$.

[54] C. van Beers, E. Berghäll and T. Poot, "R\&D internationalization, R\&D collaboration and public knowledge institutions in small economies: Evidence from Finland and the Netherlands," Research Policy, vol. 37, no. 2, 2008.

[55] B. Johansson and H. Lööf, "Innovation activities explained by firm attributes and location," Econ. Innov. New Techn., vol. 17, no. 6, pp. 533-552, 2008.

[56] C. Freeman and L. Soete, The Economics of Industrial Innovation, 3rd edition ed., Oxon: Routledge, 1997.

[57] C. M. Christensen, The Innovator's Dilemma: When New Technologies Cause Great Firms to Fail, Boston: Harvard Business School Press, 1997. 
[58] The Economist, "The last Kodak moment?," 14 January 2012. [Online]. Available: http://www.economist.com/node/21542796. [Accessed 25 September 2013].

[59] M. J. Melitz, "The Impact of Trade on Intra-Industry Reallocations and Aggregate Industry Productivity," Econometrica, vol. 71, no. 6, pp. 1695-1725, 2003.

[60] D. B. Audretsch, Innovation and Industry Evolution, Cambridge MA.: MIT Press, 1995.

[61] R. Pouder and C. S. John, "Hot spots and blind spots: Geographical clusters of firms and innovation," The Academy of Management Review, vol. 21, no. 4, pp. 1192-1225, 1996.

[62] I. R. Gordon and P. McCann, "Industrial Clusters: Complexes, Agglomeration and/or Social Networks?," Urban Studies, vol. 37, no. 3, pp. 513-532, 2000.

[63] A. Morrison, "Gatekeepers of Knowledge within Industrial Districts: Who They Are, How They Interact," Regional Studies, vol. 42, no. 6, pp. 817- 835, 2008.

[64] S. Kuznets, "Retardation in Economic Growth," Journal of Economic and Business History, vol. 1, pp. 534-560, 1929.

[65] S. G. Winter, "Schumpeterian Competition in Alternative Technological Regime," Journal of Economic Behavior and Organization, vol. 5, pp. 287-320, 1984.

[66] Z. Acs and D. Audretsch, "Innovation in Large and Small Firms: An Empirical Analysis," The American Economic Review, vol. 78, no. 4, pp. 678-690, 1988.

[67] A. Leiponen and I. Drejer, "What exactly are technological regimes?: Intra-industry heterogeneity in the organization of innovation activities," Research Policy, vol. 36, no. 8, pp. 1221-1238, 2007.

[68] M. Srholec and B. Verspagen, "The Voyage of the Beagle into innovation: explorations on heterogeneity, selection, and sectors," Industrial and Corporate Change, vol. 21, no. 5, pp. 1221-1253, 2012. 